\title{
The environmental Porter hypothesis: Theory, evidence and a model of timing of adoption
}

Citation for published version (APA):

Kriechel, B., \& Ziesemer, T. H. W. (2009). The environmental Porter hypothesis: Theory, evidence and a model of timing of adoption. Economics of Innovation and New Technology, 18(3), 267-294.

https://doi.org/10.1080/10438590801943235

Document status and date:

Published: 01/01/2009

DOI:

10.1080/10438590801943235

Document Version:

Publisher's PDF, also known as Version of record

\section{Please check the document version of this publication:}

- A submitted manuscript is the version of the article upon submission and before peer-review. There can be important differences between the submitted version and the official published version of record.

People interested in the research are advised to contact the author for the final version of the publication, or visit the DOI to the publisher's website.

- The final author version and the galley proof are versions of the publication after peer review.

- The final published version features the final layout of the paper including the volume, issue and page numbers.

Link to publication

\footnotetext{
General rights rights.

- You may freely distribute the URL identifying the publication in the public portal. please follow below link for the End User Agreement:

www.umlib.nl/taverne-license

Take down policy

If you believe that this document breaches copyright please contact us at:

repository@maastrichtuniversity.nl

providing details and we will investigate your claim.
}

Copyright and moral rights for the publications made accessible in the public portal are retained by the authors and/or other copyright owners and it is a condition of accessing publications that users recognise and abide by the legal requirements associated with these

- Users may download and print one copy of any publication from the public portal for the purpose of private study or research.

- You may not further distribute the material or use it for any profit-making activity or commercial gain

If the publication is distributed under the terms of Article $25 \mathrm{fa}$ of the Dutch Copyright Act, indicated by the "Taverne" license above, 
This article was downloaded by: [University of Maastricht]

On: 24 July 2009

Access details: Access Details: [subscription number 781062704]

Publisher Routledge

Informa Ltd Registered in England and Wales Registered Number: 1072954 Registered office: Mortimer House, 37-41 Mortimer Street, London W1T 3JH, UK

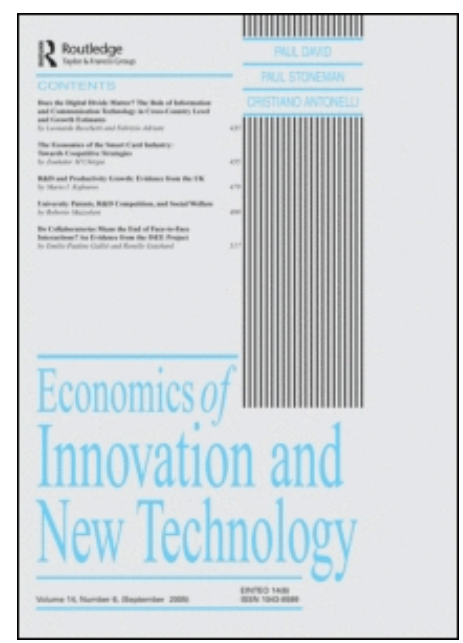

Economics of Innovation and New Technology

Publication details, including instructions for authors and subscription information:

http://www.informaworld.com/smpp/title content=t713641545

The environmental Porter hypothesis: theory, evidence, and a model of timing of adoption

Ben Kriechel ab; Thomas Ziesemer ${ }^{\circ}$

a ROA, Maastricht University, Maastricht, The Netherlands ${ }^{b}$ IZA, Bonn, Germany ${ }^{c}$ UNU-MERIT, Maastricht University, Maastricht, The Netherlands

Online Publication Date: 01 January 2009

To cite this Article Kriechel, Ben and Ziesemer, Thomas(2009)'The environmental Porter hypothesis: theory, evidence, and a model of timing of adoption',Economics of Innovation and New Technology, 18:3,267 - 294

To link to this Article: DOI: $10.1080 / 10438590801943235$

URL: http://dx.doi.org/10.1080/10438590801943235

\section{PLEASE SCROLL DOWN FOR ARTICLE}

Full terms and conditions of use: http://www.informaworld.com/terms-and-conditions-of-access.pdf

This article may be used for research, teaching and private study purposes. Any substantial or systematic reproduction, re-distribution, re-selling, loan or sub-licensing, systematic supply or distribution in any form to anyone is expressly forbidden.

The publisher does not give any warranty express or implied or make any representation that the contents will be complete or accurate or up to date. The accuracy of any instructions, formulae and drug doses should be independently verified with primary sources. The publisher shall not be liable for any loss, actions, claims, proceedings, demand or costs or damages whatsoever or howsoever caused arising directly or indirectly in connection with or arising out of the use of this material. 


\title{
The environmental Porter hypothesis: theory, evidence, and a model of timing of adoption
}

\author{
Ben Kriechel $^{\mathrm{a} *}$ and Thomas Ziesemer ${ }^{\mathrm{b}}$ \\ ${ }^{a}$ ROA, Maastricht University, Maastricht, The Netherlands; IZA, Bonn, Germany; ${ }^{b} U N U-M E R I T$, \\ Maastricht University, Maastricht, The Netherlands
}

(Received 30 August 2006, final version received 24 January 2008)

\begin{abstract}
The Porter hypothesis postulates that the costs of compliance with environmental standards may be offset by adoption of innovations they trigger. We model this hypothesis using a game of timing of technology adoption. We will show that times of adoption will be earlier if the non-adoption tax is higher. The environmental tax will turn the preemption game with low profits into a game with credible precommitment generating higher profits (pro-Porter). If there is a precommitment game without environmental taxes, the introduction of a tax will lead to lower profits (anti-Porter). An evaluation of the empirical literature indicates that the Porter hypothesis will hold even for profitmaximizing firms under multiple market imperfections such as imperfect competition, $\mathrm{X}$-inefficiency, and agency costs. These are more likely to be present in sectors with large firms. In many case studies that we have evaluated, though, we detected an element of explicit or implicit subsidies for environmentally friendly behaviour, which is in line with Pigovian policies.
\end{abstract}

Keywords: environmental policy; strategic trade theory; technology adoption; Porter hypothesis

JEL: Q2, F1, H7, O3

\section{Introduction}

Competition among firms insures efficiency in competitive markets. Environmental regulation or taxation is usually seen as a nuisance to international competition, which will lead to a distortion of competition. On the other hand, many markets are imperfectly competitive. Firms can have market power or dynamic innovation effects will disturb the efficient production of goods. In combining the environmental regulation with the innovation effects and dynamic adoption or development of new production methods, the environmental Porter hypothesis suggests that the costs of compliance with environmental standards may be offset by the innovations they trigger (see Porter 1991; Porter and van der Linde 1995a, 1995b). This may even lead to absolute advantages relative to foreign competitors. In their article (1995a) (abbreviated as PL henceforth) they state:

*Corresponding author. Email: ben@kriechel.eu 
[W]e will argue that properly designed environmental standards can trigger innovation that may partially or more than fully offset the costs of complying with them. Such 'innovation offsets,' as we call them, can not only lower the net cost of meeting environmental regulations, but can even lead to absolute advantages over firms in foreign countries not subject to similar regulations. Innovation offsets will be common because reducing pollution is often coincident with improving the productivity with which resources are used. In short, firms can actually benefit from properly crafted environmental regulations that are more stringent (or are imposed earlier) than those faced by their competitors in other countries. By stimulating innovation, strict environmental regulations can actually enhance competitiveness. (1995a, 98)

The article was greeted with scepticism, as conventional models predict ecological dumping as an outcome rather than increased environmental regulation to improve competitiveness. Nevertheless, it made economists think seriously about the gist of the Porter hypothesis: is it possible that firms could gain advantage over their foreign rivals through tougher environmental regulation? While classical trade theory offers no reason to believe in the Porter hypothesis, imperfect competition models were considered promising to find some theoretical foundations for the case study and anecdotal evidence offered by PL.

The contribution of this paper lies in our approach to model the Porter hypothesis as well as an interpretation of the empirical literature. We will argue that it is inherent to the Porter hypothesis to explicitly model the timing choice of both the home and foreign firm's technology adoption. It is the timing of adoption of new technology combined with international differences in the regulation that are at the core of the Porter hypothesis as it was originally formulated. The endogenous timing of the adoption aspect of the Porter hypothesis resulting in a competitive position of being a leader or follower has not been captured in formal theory so far, although in the literature there are other dynamic models discussed below. In this paper, we adapt the model of technology adoption of Reinganum (1981) and Fudenberg and Tirole $(1985,1987)$ for this purpose. The model allows for endogenous timing of technology adoption in a model of imperfect competition.

A point we want to make is that environmental policy may destroy a non-adoption equilibrium. It may be rational not to adopt, although no opportunities are overlooked. In a static game of technology adoption (Tirole 1988, Chapter 10) with environmental taxation, it can be shown that a sufficiently high environmental tax can force firms out of a nonadoption equilibrium. However, this falls short of the Porter hypothesis, which implies a 'competitive' advantage for the nation that introduces the environmental regulation. In the static environment, the increased competitiveness cannot be reached. If one country introduces environmental regulation that forces the 'home' firm out of a static non-adoption equilibrium, the other firm would follow immediately.

In Section 2, we introduce a dynamic model of a game of timing with a case of small environmental taxes turning a preemption game into one of precommitment. We therefore extend this to the international case, providing a model of the Porter hypothesis. We can show that the introduction of a small environmental tax can turn the dynamic game of timing from a preemption game towards one of pre-commitment in which the regulated firm is sure to have the technological lead. Thus, the Porter hypothesis can be endorsed in the sense that the introduction of a small tax ensures that the home firm would win a preemption game with certainty. This establishes an order of adoption and therefore a precommitment situation which produces higher profits for home than in the preemption game, which would have taken place without the tax. In Section 3, we consider issues of optimal timing.

We do not follow PL in emphasizing incomplete information, organizational inertia, and control problems in the theoretical part of our paper. Rather, we emphasize that all of 
their examples contain clear elements of implicit subsidies for adoption, which are equivalent to taxes on non-adoption in our model. We do not deny the role of the imperfections, but the logic is also compelling without them. In an evaluation of the empirical and theoretical literature in Section 4, we will show that both types of arguments seem to be relevant: (i) X-inefficiency and agency costs such as managerial time, alertness, and information, and (ii) strategic interactions in imperfectly competitive markets. Both are likely to be more relevant for large firms. The theoretical models trying to rationalize the Porter hypothesis clearly show that in their interpretation, the Porter hypothesis does not contradict the profit-maximization paradigm under multiple market imperfections (Ambec and Barla 2005).

\subsection{Earlier literature}

Ulph (1996a,b) constructs a Brander-Spencer type of strategic trade model with Cournot competition. Firms can invest in technology-affecting variable costs but not the accompanying pollution. He shows that the strategic interaction between producers reduces the government's incentive to loosen environmental regulation. He concludes, though, that the reduction of pollution with the lowering of the variable costs could change that result. This is the path that Simpson and Bradford III (1996) pick up. They model the firms in a similar fashion, with the exception that R\&D not only lowers marginal costs, but also the emission of the pollutant. The government uses effluent taxation to maximize the domestic firm's profits net of the environmental externalities of production. The government is able to force the firm into a Stackelberg-leader position relative to its foreign competitor. For some special cases of specifications and numerical parameter values, they are able to construct a strengthening of regulation, resulting in a shift of profits from foreign to domestic firms. However, they emphasize that this is not a general result and it is unlikely that environmental regulation should be used as a policy device to induce industrial advantage. Greaker (2003) models the Porter hypothesis by assuming that due to the abatement technology the environment is an inferior input in the production process. For some ranges of environmental taxation, it is shown to increase competitiveness. However, the impact on profits remains ambiguous. Feess and Taistra (2000) model a two-period game with Cournot competition. The environmentally friendly technology is assumed to lead to a decrease of unit costs in the second period, however, not in a way that reduces overall costs. Policy agencies of the foreign nation are assumed to stochastically imitate the national environmental regulation. Bertrand-type imperfect competition models were introduced in the context of strategic environmental trade policy in the paper by Barrett (1994). In the context of cost-saving research, Ulph (1996) shows both for environmental taxation and for environmental standards that firms can benefit from tighter regulation if only the governments act strategically, but firms do not.

Principal-agent models of the Porter hypothesis are set in the context of organizational inefficiencies. In this model, the incentives between principal and agent over the choice of projects are misaligned. Environmental regulation helps to realign the preferences of principal and agent, hence the efficiency of the firm increases (see, for example, Schmutzler (2001) and Klein and Rothfels (1999)). Ambec and Barla (2002) show that, by reducing agency costs, an environmental regulation may enhance pollution-reducing innovation while at the same time increasing firms' private benefit.

Popp (2005) shows that under uncertain R\&D, when firms underestimate the profitability, environmental regulation may push them to do more profitable R\&D. His simulations show that complete offsets occur frequently, though not in a majority of cases. 
Xepapadeas and de Zeeuw (1999) and Mohr (2002) use a general equilibrium framework with a large number of agents, external economies of scale in production, and discrete changes in technology. New technologies are modelled with an industry learning curve, and firms are initially stuck in a non-innovating equilibrium. Environmental regulation enforces the adoption of 'new technology', hence allowing for subsequent learning. Feichtinger et al. (2005) extend on the framework of Xepapadeas and Zeeuw (1999) by introducing technological progress within the capital stock of firms. The dynamic determination of the optimal age of the capital stock, representing the degree of capital adoption, is then related to the level of environmental regulation.

Related to our paper is Hübner (2002). Using a duopoly model of patent races, which are similar to our models of technology adoption, she shows that stricter environmental policy might increase the probability of a sleeping patent instead of encouraging environmental technological progress, but the reversed case is also possible: environmental policy may activate otherwise sleeping patents.

Also, the paper of Osang and Nandy (2003) shows that in a symmetric Cournot duoploy model with pollution, firms can stick to high-pollution production processes, or to low-pollution production processes, depending on the government regulation. Thus, for a technology adoption process, they show the adoption of new production processes as a reaction to competitive pressures combined with government regulation.

Empirical support for the hypothesis is based on case study evidence, which will be reviewed in the next subsection. There are, however, two general empirical attempts to test parts of PL: Palmer, Oates, and Portney (1995) provide empirical arguments explaining why full offsets are rather unlikely. They base their argument on information provided by entrepreneurs and find no direct evidence for the Porter hypothesis. Jaffe and Palmer (1997) critically evaluate the Porter hypothesis. They attempt to empirically 'test' the hypothesis, but find no evidence supporting it. This empirical evaluation is based on the link between the stringency of environmental regulation and $R \& D$, but not on adoption.

\section{Environmental taxes in a game of timing}

In static models of technology adoption, firms either both adopt or not at all even if only one country raises a tax. Intermediate cases are not possible in this setting. However, Reinganum (1981) and the extension by Fudenberg and Tirole (1985) provide such a model where firms either adopt earlier or later. We apply the model to the case of environmental regulation in the spirit of the Porter hypothesis. This allows us to theoretically evaluate the hypothesis, as we allow for dynamic effects which are crucial in the argumentation leading towards an increased competitiveness.

Here we restate their model for the case of two firms and introduce an environmental non-adoption tax, $\tau .{ }^{1}$ We show that all possible modes of adoption-preemption, following, and joint late adoption - are earlier, the higher the adoption tax. Moreover, an environmental tax ensures a precommitment position for the domestic firm. But it decreases profits when increased further. A low environmental tax ensures a preemptive position of the domestic firm, establishes an order of adoption, and therefore leads also to a precommitment associated with higher profit for the home firm.

Let $\pi_{0}(0)-\tau$ denote after-tax profits of a firm if no firm has yet adopted. $\pi_{0}(1)-\tau$ denotes after-tax profits of a firm if only the other firm has adopted. $\pi_{1}(1)$ is the profit of a firm which has adopted but the other firm has not. $\pi_{1}(2)$ is the profit of a firm if both have adopted. ${ }^{2}$ 
There is a cost $c(t)$ associated with adoption. Early adoption of new technology is more costly, hence $c$ is a function of time such that early adoption is more costly $\left(c^{\prime}<0\right) .{ }^{3}$ Using superscript 2 for the firm that is second to adopt, the follower, and superscript 1 for the leader, the value of the firms with adoption times $T_{1}$ and $T_{2}$ can be written as follows: ${ }^{4}$

$$
\begin{aligned}
& V^{1}\left(T_{1}, T_{2}\right)=\int_{0}^{T_{1}}\left[\pi_{0}(0)-\tau\right] \mathrm{e}^{-r t} \mathrm{~d} t+\int_{T_{1}}^{T_{2}} \pi_{1}(1) \mathrm{e}^{-r t} \mathrm{~d} t+\int_{T_{2}}^{\infty}\left[\pi_{1}(2)\right] \mathrm{e}^{-r t} \mathrm{~d} t-c\left(T_{1}\right) \\
& V^{2}\left(T_{2}, T_{1}\right)=\int_{0}^{T_{1}}\left[\pi_{0}(0)-\tau\right] \mathrm{e}^{-r t} \mathrm{~d} t+\int_{T_{1}}^{T_{2}}\left[\pi_{0}(1)-\tau\right] \mathrm{e}^{-r t} \mathrm{~d} t+\int_{T_{2}}^{\infty} \pi_{1}(2) \mathrm{e}^{-r t} \mathrm{~d} t-c\left(T_{2}\right) .
\end{aligned}
$$

Firms differ only in two aspects. First, in the second phase, between $T_{1}$ and $T_{2}$, firm 1 has adopted and firm 2 has not. Second, the present values of the cost of adoption, $c$, at different points in time are different, as $c\left(T_{2}\right)<c\left(T_{1}\right)$ given assumption 4 below.

Assumptions made on the magnitude of the profit and cost items are the following:

(1) There are decreasing returns in the rank of adoption: $\pi_{1}(1)>\pi_{1}(2)$.

(2) The difference in profits from adoption, at time zero, is not larger than the decrease in the costs of adopting while waiting: $\pi_{1}(1)-\left[\pi_{0}(1)-\tau\right] \leq-c^{\prime}(0)$ for all $\tau \geq$ 0 . Therefore, immediate adoption is not profitable unless the equality part of the equation holds.

(3) Second adoption always becomes profitable after some time: $\inf _{t}\left\{c(t) \mathrm{e}^{r t}\right\}<$ $\left\{\pi_{1}(2)-\left[\pi_{0}(1)-\tau\right]\right\} / r$ for all $\tau \geq 0$.

(4) Current costs of adoption are falling but decreasingly so: for all $t,\left(c(t) \mathrm{e}^{r t}\right)^{\prime}<0$, $\left(c(t) \mathrm{e}^{r t}\right)^{\prime \prime}>0$.

The decreasing returns in the rank of adoption assumption (1) implies that adoption is more profitable, if one is the only producer that has adoption.

No general claim is made here or by PL that early adoption or first moving is advantageous in general (see Hoppe (2002) for a survey of theory and evidence), but the case studies which support the Porter hypothesis are those of advantageous early adoption. The ideas of PL (1995b, 124-9) are clearly based on the assumption of a first mover advantage. Notice though that $\pi$ captures profits gross of adoption costs, whereas early adoption and first mover advantage are derived on the basis of both gross profits and adoption costs, $c$, considered below. Other outcomes are shown to be possible as well.

The second assumption merely excludes cases of immediate adoption. The third assumption insures that the new technology is superior to the old one in the sense that it can generate more profits once the costs of adoption have decreased sufficiently. ${ }^{5}$ Immediate adoption is not relevant here, because under immediate adoption there would be no room for regulations to speed up innovation (offsets), which are typical of the Porter hypothesis.

Finally, the last assumption gives a shape to the cost of adoption function. The decreasing costs of adoption is straightforward.

The assumptions on the order of the profit terms as made are essential to having a sequential adoption problem. They are satisfied in a linear Cournot model (Tirole 1988; Hoppe 2002). Deriving them jointly with other possible outcomes would increase the complexity substantially.

It is obvious from assumptions (2) and (3) that taxes on non-adoption are equivalent to subsidies for adoption. There are many examples for this type of taxes or subsidies 
summarized in Table 4. The examples serve two purposes: they show that there is a lot of emphasis on adoption in PL, leading to innovation offsets, and there are often implicit or explicit taxes or subsidies involved.

\subsection{Games of timing: national case}

In the national case, both firms are regulated by the same national policy, hence they both operate under non-adoption tax. We will develop the optimal timing of adoption in the case of a national competition first, i.e. where both firms are faced with the same environmental regulation and taxation. In Section 2.2, this will be changed to the international case in which only the home firm faces an environmental non-adoption tax. The derivations of the optimal timings of this section can be applied to the international case by setting the foreign firm's tax equal to zero.

Precommitment allows a firm to commit to being either follower or leader. However, in order for precommitment to matter, it has to be credible. We will argue below that the environmental tax will eventually allow the firm to credibly precommit. ${ }^{6}$

Given credible precommitment on the order of adoption, the optimal adoption time for the leader, $T_{1}$, can be found from the first-order condition

$$
\frac{\mathrm{d} V^{1}}{\mathrm{~d} T_{1}}=\left[\pi_{0}(0)-\tau\right] \mathrm{e}^{-r T_{1}}-\pi_{1}(1) \mathrm{e}^{-r T_{1}}-c^{\prime}\left(T_{1}\right)=0 .
$$

The optimal adoption time for the follower in case of a precommitment can similarly be found from the first-order condition

$$
\frac{\mathrm{d} V^{2}}{\mathrm{~d} T_{2}}=\left[\pi_{0}(1)-\tau\right] \mathrm{e}^{-r T_{2}}-\pi_{1}(2) \mathrm{e}^{-r T_{2}}-c^{\prime}\left(T_{2}\right)=0 .
$$

If the leader has already adopted, the last equation determines the followers optimal time, $T_{2}^{*}$. Note that the equations determine the optimal timing for the follower irrespective of the existence or absence of precommitment. Thus, it allows us to calculate the impact of the environmental tax on the followers' optimal adoption time, by differentiating with respect to the level of environmental taxation $\tau$ :

$$
\frac{\mathrm{d} T_{2}^{*}}{\mathrm{~d} \tau}=-\frac{-\mathrm{e}^{-r T_{2}}}{\left[\pi_{0}(1)-\tau\right](-r) \mathrm{e}^{-r T_{2}}+r \pi_{1}(2) \mathrm{e}^{-r T_{2}}-c^{\prime \prime}\left(T_{2}\right)}=-\frac{-\mathrm{e}^{-r T_{2}}}{-r c^{\prime}\left(T_{2}\right)-c^{\prime \prime}\left(T_{2}\right)}<0 .
$$

The second part of the equation has been obtained by insertion of $c^{\prime}$ from Equation (4). Assumption (4) implies that the denominator, which is also the second-order condition of Equation (4), has a negative sign.

The dependence of timing of the leader upon the environmental tax can be derived in a similar fashion:

$$
\frac{\mathrm{d} T_{1}^{*}}{\mathrm{~d} \tau}=-\frac{-\mathrm{e}^{-r T_{1}}}{\left[\pi_{0}(0)-\tau\right](-r) \mathrm{e}^{-r T_{1}}+r \pi_{1}(1) \mathrm{e}^{-r T_{1}}-c^{\prime \prime}\left(T_{1}\right)}=-\frac{-\mathrm{e}^{-r T_{1}}}{-r c^{\prime}\left(T_{1}\right)-c^{\prime \prime}\left(T_{1}\right)}<0 .
$$

This leads us to the following proposition.

PROPOSITION 2.1 The leader and the follower adopt earlier under precommitment if the environmental tax is larger. 
This proposition, while not surprising, is important in the sense that the tax affects both the leader and the follower by shortening the adoption time. Especially, the effect on the follower is often overlooked, while it leads to important changes: the leader will have lower overall gains from leading if the follower adopts earlier. While from the environmental point of view, the effect of regulation is improved (quickened) adoption of the more environmental friendly technology by both types of firms.

Note that the previous results were derived under the assumption that there is one obvious leader and an obvious follower. This could be achieved by credible precommitment. If, however, there is no precommitment on the order of adoption, preemption might be a rational choice for firms. The timing of preemption can be found as follows. The leader's payoff if she succeeds in preempting at time $t$ is

$$
L(t)= \begin{cases}V\left(t, T_{2}^{*}\right) & \text { if } t<T_{2}^{*}, \\ V(t, t) & \text { if } t \geq T_{2}^{*}\end{cases}
$$

where $V(x, y)$ is the value of adopting at time $t=x$, given adoption by the other firm at $t=y$. The followers payoff if he is preempted at time $t$ is

$$
F(t)= \begin{cases}V\left(T_{2}^{*}, t\right) & \text { if } t<T_{2}^{*} \\ V(t, t) & \text { if } t \geq T_{2}^{*}\end{cases}
$$

If both firms adopt simultaneously, the payoff for each firm is $M(T)=V(t, t)$.

If $t<T_{2}^{*}, L(t)>M(t)$ and $F(t)>M(t)$.

The important issue here is to figure out how the timing of precommitment and following are affected by environmental taxes. There are several issues here. First, what is the optimal moment of adoption, given that a firm wants to preempt (and similarly given that one wants to follow), and secondly, what is the difference between leader and follower payoff. Thus, subtracting the payoff of a follower from that of a leader, and plugging in Equations (3) and (4), one finds that the first- and second-order conditions of maximizing this difference are

$$
\begin{aligned}
{[L(t)-F(t)]^{\prime} } & =-\pi_{1}(1) \mathrm{e}^{-r T_{1}}-c^{\prime}\left(T_{1}\right)+\left[\pi_{0}(1)-\tau\right] \mathrm{e}^{-r T_{1}}=0, \\
{[L(t)-F(t)]^{\prime \prime} } & =-r c^{\prime}-c^{\prime \prime}<0,
\end{aligned}
$$

because of assumption (4). As $L(t)-F(t)$ has a maximum, each firm would like to preempt the other. As in Fudenberg and Tirole (1985), $L(0)<F(0)$ from assumption (2) and $L\left(T_{2}^{*}\right)=F\left(T_{2}^{*}\right)$ from the definitions of $L$ and $F$, and $L\left(T_{1}^{*}\right)>F\left(T_{1}^{*}\right)$ from $V^{1}\left(T_{1}^{*}, T_{2}^{*}\right)>$ $V^{2}\left(T_{2}^{*}, T_{1}^{*}\right)$ under precommitment. Together with the monotonicity of the value functions, this information implies that there must be a point in time, $T_{1}$, at which $L\left(T_{1}\right)=F\left(T_{1}\right)$ (cf. Fudenberg and Tirole 1985, 386). This is the first profitable point in time for preemption. Problematic in the model with preemption is that, given symmetric firms, both would like to preempt at the same time or not at all.

Equating the values of the firms, $V^{1,2}$, for this point in time yields

$$
L\left(T_{1}\right)-F\left(T_{1}\right)=\int_{T_{1}}^{T_{2}} \pi_{1}(1) \mathrm{e}^{-r t} \mathrm{~d} t-c\left(T_{1}\right)-\left\{\int_{T_{1}}^{T_{2}}\left[\pi_{0}(1)-\tau\right] \mathrm{e}^{-r t} \mathrm{~d} t-c\left(T_{2}\right)\right\}=0
$$

PROPOSITION 2.2 Under preemption, the timing of preemptive adoption will be earlier if the environmental tax is higher. 
This follows from Equation (11), which, differentiated with respect to the environmental tax, implies

$$
\frac{\mathrm{d} T_{1}}{\mathrm{~d} \tau}=-\frac{\int_{T_{1}}^{T_{2}} \mathrm{e}^{-r t} \mathrm{~d} t}{-\pi_{1}(1) \mathrm{e}^{-r T_{1}}+\left[\pi_{0}(1)-\tau\right] \mathrm{e}^{-r T_{1}}-c^{\prime}\left(T_{1}\right)}<0 .
$$

Hence, the timing of the preemptive point of time is pushed forward.

Now suppose that there is joint late adoption and therefore $M=V^{1}=V^{2}$. This is the case in which the point of preemption is not sufficiently profitable, so that both firms wait. Insertion of the value functions given above for $T_{1}=T_{2}$ yields

$$
M=V^{1,2}\left(T_{2}, T_{1}\right)=\int_{0}^{T_{1}}\left[\pi_{0}(0)-\tau\right] \mathrm{e}^{-r t} \mathrm{~d} t+\int_{T_{2}}^{\infty} \pi_{1}(2) \mathrm{e}^{-r t} \mathrm{~d} t-c\left(T_{2}\right) .
$$

The optimal joint adoption time is found by maximization of $M$ with respect to $T=T_{1}=T_{2}$. The first-order condition is

$$
\frac{\mathrm{d} M}{\mathrm{~d} T}=\left[\pi_{0}(0)-\tau\right] \mathrm{e}^{-r T}-\pi_{1}(2) \mathrm{e}^{-r T}-c^{\prime}(T)=0 .
$$

From this, we can calculate the impact of an increase in the environmental tax on the timing of joint adoption:

$$
\frac{\mathrm{d} T}{\mathrm{~d} \tau}=-\frac{-\mathrm{e}^{-r T}}{-r\left[\pi_{0}(0)-\tau\right] \mathrm{e}^{-r T}+r \pi_{1}(2) \mathrm{e}^{-r T}-c^{\prime \prime}(T)}<0 .
$$

PROPOSITION 2.3 Joint late adoption takes place earlier under a higher environmental tax.

We have shown that in all cases the environmental tax moves the timing of adoption towards an earlier point in time. It is important to note that these results are to be expected. In the next section, the analysis will be extended to the case in which we have unequal environmental taxes.

\subsection{Games of timing: international case}

Now let us suppose that environmental regulation is one-sided. The firms are located in different countries. Firm 1 is located in 'home', and firm 2 is located in 'foreign', competing on a third market without transport costs or tariffs. Foreign does not introduce any environmental regulation. Both the third market assumption and the fact that foreign does not introduce any environmental regulation are simplifying - but for the ease of calculation necessary assumptions. The first excludes in repercussions (on, e.g. welfare) of a competition in the home country that a government would be interested in, whereas the second assumption of no foreign environmental tax is simply the extreme case of having lower taxes.

Table 1 summarizes in general terms the payoff for the firms. Now $\pi_{0}(0)-\tau$ are after-tax profits of the home firm and $\pi_{0}(0)$ for the foreign firm if no firm has yet adopted. $\pi_{0}(1)-\tau$ are after-tax profits of the home firm if only the other firm has adopted and $\pi_{0}(1)$ for the foreign firm. $\pi_{1}(1)$ is the profit of the home firm which has adopted while the other, foreign firm has not. $\pi_{1}(2)$ is the profit of either firm if both have adopted. We use superscripts ' $h$ ' and ' $f$ ' for home and foreign respectively. 
Table 1. Payoff in the game of timing.

\begin{tabular}{lll}
\hline & \multicolumn{2}{c}{ Foreign } \\
\cline { 2 - 3 } & Lead & Follow \\
\hline Home & & \\
Lead & $\left(L^{h}, L^{f}\right)$ & $\left(L^{h}, F^{f}\right)$ \\
Follow & $\left(F^{h}, L^{f}\right)$ & $\left(F^{h}, F^{f}\right)$ \\
\hline
\end{tabular}

As in the national case, let us first examine the case in which the home firm is precommitted to be the follower. In this case,

$$
\begin{aligned}
F^{h} \equiv V_{F}^{h}\left(T_{2}^{h}, T_{1}^{f}\right)= & \int_{0}^{T_{1}^{f}}\left[\pi_{0}(0)-\tau\right] \mathrm{e}^{-r t} \mathrm{~d} t+\int_{T_{1}^{f}}^{T_{2}^{h}}\left[\pi_{0}(1)-\tau\right] \mathrm{e}^{-r t} \mathrm{~d} t \\
& +\int_{T_{2}^{h}}^{\infty} \pi_{1}(2) \mathrm{e}^{-r t} \mathrm{~d} t-c\left(T_{2}^{h}\right) .
\end{aligned}
$$

And for the foreign, precommitted leader, we have

$$
\begin{aligned}
L^{f} \equiv V_{L}^{f}\left(T_{1}^{f}, T_{2}^{h}\right)= & \int_{0}^{T_{1}^{f}} \pi_{0}(0) \mathrm{e}^{-r t} \mathrm{~d} t+\int_{T_{1}^{f}}^{T_{2}^{h}} \pi_{1}(1) \mathrm{e}^{-r t} \mathrm{~d} t \\
& +\int_{T_{2}^{h}}^{\infty} \pi_{1}(2) \mathrm{e}^{-r t} \mathrm{~d} t-c\left(T_{1}^{f}\right) .
\end{aligned}
$$

Given that home follows, we can determine the optimal adoption time:

$$
T_{2}^{h}: \frac{\partial V_{F}^{h}}{\partial T_{2}^{h}}=\left[\pi_{0}(1)-\tau\right] \mathrm{e}^{-r T_{2}^{h}}-\pi_{1}(2) \mathrm{e}^{-r T_{2}^{h}}-c^{\prime}\left(T_{2}^{h}\right)=0
$$

We can see that $T_{2}^{h}(r, \tau)$ is independent of $T_{1}$. Further, $\partial T_{2}^{h} / \partial \tau<0$. Hence, we can state the following.

PROPOSITION 2.4 Home, as the follower, adopts earlier if the environmental tax is larger, decreasing the time that a foreign firm can reap the benefits of early adoption.

Examining the impact of the environmental tax, $\tau$, on the timing of the foreign leader, we find

$$
T_{1}^{f}: \frac{\partial V_{L}^{f}}{\partial T_{1}^{f}}=\pi_{0}(0) \mathrm{e}^{-r T_{1}^{f}}-\pi_{1}(1) \mathrm{e}^{-r T_{1}^{f}}-c^{\prime}\left(T_{1}^{f}\right)=0 .
$$

Hence, $T_{1}^{f}$ is independent of $\tau$ and $T_{2}^{H}$. The timing of foreign leadership is not affected by the tax $\tau$ imposed by the home government. 
Let us now turn to the case in which home is precommitted leader and foreign is follower:

$$
\begin{aligned}
& F^{f} \equiv V_{F}^{f}\left(T_{2}^{f}, T_{1}^{h}\right)=\int_{0}^{T_{1}^{h}} \pi_{0}(0) \mathrm{e}^{-r t} \mathrm{~d} t+\int_{T_{1}^{h}}^{T_{2}^{f}} \pi_{0}(1) \mathrm{e}^{-r t} \mathrm{~d} t+\int_{T_{2}^{f}}^{\infty} \pi_{1}(2) \mathrm{e}^{-r t} \mathrm{~d} t-c\left(T_{2}^{f}\right), \\
& L^{h} \equiv V_{L}^{h}\left(T_{1}^{h}, T_{2}^{f}\right)=\int_{0}^{T_{1}^{h}}\left[\pi_{0}(0)-\tau\right] \mathrm{e}^{-r t} \mathrm{~d} t+\int_{T_{1}^{h}}^{T_{2}^{f}} \pi_{1}(1) \mathrm{e}^{-r t} \mathrm{~d} t+\int_{T_{2}^{f}}^{\infty} \pi_{1}(2) \mathrm{e}^{-r t} \mathrm{~d} t-c\left(T_{1}^{h}\right) .
\end{aligned}
$$

Again, we can determine the optimal timing of $T_{2}$, given that foreign is committed to follow.

$$
T_{2}^{f}: \frac{\partial V_{F}^{f}}{\partial T_{2}^{f}}=\pi_{0}(1) \mathrm{e}^{-r T_{2}^{f}}-\pi_{1}(2) \mathrm{e}^{-r T_{2}^{f}}-c^{\prime}\left(T_{2}^{f}\right)=0 .
$$

Once more, the timing of the foreign firm's adoption, here $T_{2}^{f}$, is independent of $\tau$, but also of the timing of early adoption $T_{1}^{h}$. Further note that, $T_{2}^{H}<T_{2}^{f}$, because Equations (18) and (22) differ only by $\tau$ in Equation (18).

For the timing of home, as the precommitted leader, we get

$$
T_{1}^{h}: \frac{\partial V_{L}^{h}}{\partial T_{1}^{h}}=\left[\pi_{0}(0)-\tau\right] \mathrm{e}^{-r T_{1}^{h}}-\pi_{1}(1) \mathrm{e}^{-r T_{1}^{h}}-c^{\prime}\left(T_{1}^{h}\right)=0 .
$$

Note that the time of adoption is earlier, the higher the environmental tax: $\partial T_{1}^{h} / \partial \tau<0$. Home, as a leader, adopts faster than foreign as a leader, i.e. $T_{1}^{h}<T_{1}^{f}$ because of Equations (19) and (23).

PROPOSITION 2.5 Foreign adopts slower-given that the environmental tax is smaller or equal to zero - than the home firm both as leader and follower.

\section{Returns to leadership and following}

We have shown above that - under precommitment - home adopts earlier than the foreign firm, both as a leader and as a follower. Hence, we can order all timings of adoption in the following way: $T_{1}^{h}<T_{1}^{f}<T_{2}^{h}<T_{2}^{f}$, which is also depicted in Figure 1 .

We have to make sure, though, that the firms actually want to be leader or follower. In order to examine this, we have to examine the difference between leadership returns $L$ and follower returns $F$. Table 2 summarizes the payoff, which will be specified below. Home

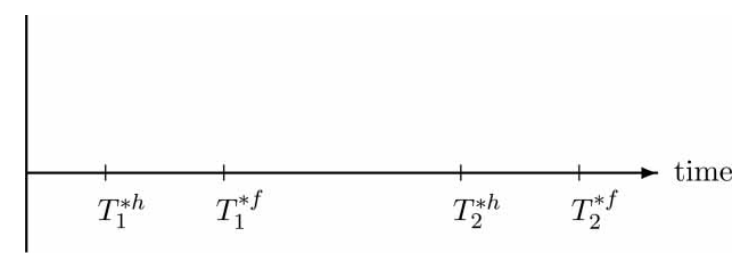

Figure 1. Timing of adoption under precommitment. 
Table 2. Preferences of the firm.

\begin{tabular}{ccc}
\hline & \multicolumn{2}{c}{ Foreign } \\
\cline { 2 - 3 } & Lead & Follow \\
\hline Home & & \\
Lead & $L^{h}-F^{h}>0$, & $L^{h}-F^{h}>0$, \\
& $L^{f}-F^{f}>0$ & $L^{f}-F^{f}<0$ \\
Follow & $L^{h}-F^{h}<0$, & $L^{h}-F^{h}<0$, \\
& $L^{f}-F^{f}>0$ & $L^{f}-F^{f}<0$ \\
\hline
\end{tabular}

would like to lead if $L^{h}-F^{h} \geq 0$ and follow otherwise. Subtracting the maximized value of Equation (16) from (21) yields

$$
\begin{aligned}
L^{* h}-F^{* h}= & \int_{T_{1}^{* h}(\tau)}^{T_{1}^{* f}}\left[\pi_{1}(1)-\pi_{0}(0)+\tau\right] \mathrm{e}^{-r t} \mathrm{~d} t+\int_{T_{1}^{* f}}^{T_{2}^{* h}(\tau)}\left[\pi_{1}(1)-\pi_{0}(1)+\tau\right] \mathrm{e}^{-r t} \mathrm{~d} t \\
& +\int_{T_{2}^{* h}(\tau)}^{T_{2}^{* f}}\left[\pi_{1}(1)-\pi_{1}(2)\right] \mathrm{e}^{-r t} \mathrm{~d} t-\left[c\left(T_{1}^{* h}(\tau)\right)-c\left(T_{2}^{* h}(\tau)\right)\right] .
\end{aligned}
$$

\subsubsection{Preemption}

Home will try to preempt as long as $L^{* h}-F^{* h}>0$, and being the leader at the preemption time $T$ yields at least the same revenue as being a follower. At this point, the partial differential of Equation (11), i.e. the first profitable time of preemption, with respect to the height of the tax $\tau$ is evaluated:

$$
\begin{aligned}
& \left.\frac{\partial T_{1}^{h}}{\partial \tau}\right|_{L^{h}\left(T_{1}^{h}\right)=F^{h}\left(T_{2}^{* h}\right)}
\end{aligned}
$$

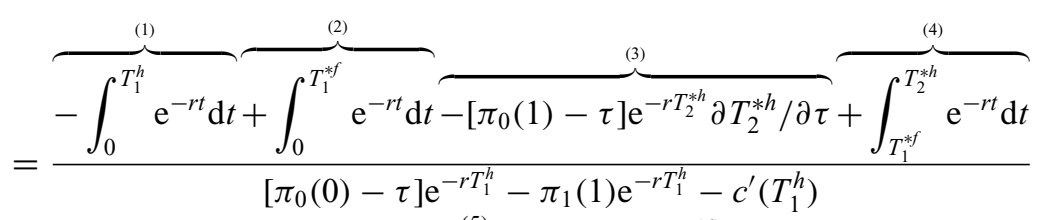

$$
\begin{aligned}
& \text { (5) (6) } \\
& -\frac{\overbrace{\pi_{1}(2) \mathrm{e}^{-r T_{2}^{* h}} \partial T_{2}^{* h} / \partial \tau} \overbrace{+c^{\prime} \partial T_{2}^{* h} / \partial \tau}}{\left[\pi_{0}(0)-\tau\right] \mathrm{e}^{-r T_{1}^{h}}-\pi_{1}(1) \mathrm{e}^{-r T_{1}^{h}}-c^{\prime}\left(T_{1}^{h}\right)} .
\end{aligned}
$$

The denominator is greater than zero as $L^{h}-F^{h}=0$ is before (in time) the maximum. We will evaluate the sign of the numerator by the parts indicated with the brackets above them: The first part (1)

$$
-\left[\frac{1}{-r} \mathrm{e}^{-r t}\right]_{0}^{T_{1}^{h}}=-\left[\frac{1}{-r} \mathrm{e}^{-r T_{1}^{h}}-\frac{1}{-r}\right]<0 \text { as } T_{1}^{h}>0
$$

has the economic interpretation that the environmental tax reduces the profit of leadership in the first phase, and therefore the first profitable time of adoption is later. 
The second part (2) is greater than zero:

$$
\int_{0}^{T_{1}^{* f}} \mathrm{e}^{-r t} \mathrm{~d} t=\left[\frac{1}{-r} \mathrm{e}^{-r t}\right]_{0}^{T_{1}^{* f}}=\frac{1}{-r}\left[\mathrm{e}^{-r T_{1}^{* f}}-1\right]>0 \text { as } T_{1}^{*}>0 .
$$

The tax reduces the follower profit in the first phase, and the company has an earlier first profitable time of adoption.

The third, fifth, and sixth terms are all zero, as the envelope theorem applies to $F^{* h}$, and therefore $\partial T_{2}^{h *} / \partial \tau$-terms sum to zero and drop out.

The fourth term ensures that $\partial T_{1}^{h} / \partial \tau<0$, i.e. earlier preemption point of time for home with higher environmental taxation. Hence, the taxation insures that the home firm always accepts earlier preemption times than foreign, because taxes guarantee lower profits as follower, and will thus win preemption games with certainty (rather than with a $50 \%$ chance).

PROPOSITION 2.6 A non-adoption tax in one country ensures that the firm in that country can preempt earlier than the firm in the other country. This establishes the order of adoption and therefore the precommitment case becomes relevant, where the home firm gets higher profits than in the preemption game.

\subsubsection{Joint late adoption}

Another possibility is that both firms prefer to defer the investment in the new technology, yielding a joint late adoption equilibrium: $M(t)=V(t, t)$.

The value function for foreign will then be:

$$
M^{f}(t)=\int_{0}^{\hat{T}_{1}} \pi_{0}(0) \mathrm{e}^{-r t} \mathrm{~d} t+\int_{\hat{T}_{1}}^{\infty} \pi_{1}(2) \mathrm{e}^{-r t} \mathrm{~d} t-c(t) .
$$

The value function for the home firm mirrors that of the foreign firm, with the inclusion of the environmental tax for the non-adoption time.

$$
M^{h}(t)=\int_{0}^{\hat{T}_{1}}\left[\pi_{0}(0)-\tau\right] \mathrm{e}^{-r t} \mathrm{~d} t+\int_{\hat{T}_{1}}^{\infty} \pi_{1}(2) \mathrm{e}^{-r t} \mathrm{~d} t-c(t) .
$$

The first-order conditions for $c(t)$ are

$$
\begin{aligned}
\frac{\partial M^{f}}{\partial \hat{T}_{1}} & =\pi_{0}(0) \mathrm{e}^{-r \hat{T}_{1}}-\pi_{1}(2) \mathrm{e}^{-r \hat{T}_{1}}-c^{\prime}\left(\hat{T}_{1}\right)=0 \\
& =\left(\pi_{0}(0)-\pi_{1}(2)\right) \mathrm{e}^{-r \hat{T}_{1}}-c^{\prime}\left(\hat{T}_{1}\right)=0, \\
\frac{\partial M^{h}}{\partial \hat{T}_{1}} & =\left(\pi_{0}(0)-\tau-\pi_{1}(2)\right) \mathrm{e}^{-r \hat{T}_{1}}-c^{\prime}\left(\hat{T}_{1}\right)=0 .
\end{aligned}
$$

This environmental tax destroys late adoption, as it leads to earlier adoption than the foreign firm, hence destroying the joint late adoption equilibrium. If under some circumstances joint late adoption was the equilibrium outcome among equal firms, it will be destroyed by the environmental tax levied asymmetrically on the home firm.

Proposition 2.7 Even small taxes create a precommitment against (late) joint adoption. 


\subsubsection{Returns to leadership}

The change of 'leadership returns' with respect to the environmental tax, $\tau$, for home is evaluated below. Differentiation with respect to $T_{1}^{h}$ sums up to zero when the envelope theorem is applied to $L^{h}$ and those with respect to $T_{2}^{h}$ when it is applied to $F^{h}$. Therefore, only the direct effects matter.

$$
\begin{aligned}
\frac{\partial\left(L^{h}-F^{h}\right)}{\partial \tau} & =\int_{T_{1}^{h}(\tau)}^{T_{1}^{f}} \mathrm{e}^{-r t} \mathrm{~d} t+\int_{T_{1}^{f}}^{T_{2}^{h}(\tau)} \mathrm{e}^{-r t} \mathrm{~d} t \\
& =\left[-\frac{1}{r} \mathrm{e}^{-r t}\right]_{T_{1}^{h}}^{T_{1}^{f}}+\left[-\frac{1}{r} \mathrm{e}^{-r t}\right]_{T_{1}^{f}}^{T_{2}^{h}} \\
& =-\frac{1}{r}\left[\mathrm{e}^{-r T_{1}^{f}}-\mathrm{e}^{-r T_{1}^{h}}\right]-\frac{1}{r}\left[\mathrm{e}^{-r T_{2}^{h}}-\mathrm{e}^{-r T_{1}^{f}}\right] \\
& =-\frac{1}{r}\left[\mathrm{e}^{-r T_{1}^{h}}-\mathrm{e}^{-r T_{2}^{h}}\right]>0 .
\end{aligned}
$$

A higher non-adoption tax increases the desire to lead, because it reduces profits from followership, $F^{h}$, more than from leadership, $L^{h}$. Similarly, the foreign firm would like to lead if $L^{f}-F^{f} \geq 0$.

$$
\begin{aligned}
L^{f}-F^{f}= & \int_{T_{1}^{h}}^{T_{1}^{f}}\left[\pi_{0}(0)-\pi_{0}(1)\right] \mathrm{e}^{-r t} \mathrm{~d} t+\int_{T_{1}^{f}}^{T_{2}^{h}}\left[\pi_{1}(1)-\pi_{0}(1)\right] \mathrm{e}^{-r t} \mathrm{~d} t \\
& +\int_{T_{2}^{h}}^{T_{2}^{f}}\left[\pi_{1}(2)-\pi_{0}(1)\right] \mathrm{e}^{-r t} \mathrm{~d} t-\left[c\left(T_{1}^{f}\right)-c\left(T_{2}^{f}\right)\right] .
\end{aligned}
$$

Now the effect of the 'home tax' on foreign's willingness to lead (or follow) is captured in the following derivative:

$$
\frac{\partial\left(L^{f}-F^{f}\right)}{\partial \tau}=-\left[\pi_{0}(0)-\pi_{0}(1)\right] \mathrm{e}^{-r T_{1}^{h}} \frac{\partial T_{1}^{h}}{\partial \tau}+\pi_{1}(1) \mathrm{e}^{-r T_{2}^{h}} \frac{\partial T_{2}^{h}}{\partial \tau}-\pi_{1}(2) \mathrm{e}^{-r T_{2}^{h}} \frac{\partial T_{2}^{h}}{\partial \tau} .
$$

We cannot fully sign the derivative. ${ }^{7}$ Therefore, we give a numerical simulation in the next subsection.

\subsection{Simulations}

The cost function in these numerical simulations will be parametrized as $c(t)=100 \mathrm{e}^{-\alpha t}$. The assumption of $c^{\prime}<0$ and $c^{\prime \prime}>0$ are then fulfilled for all economically sensible parameter values of $\alpha \in \mathbb{R}^{+}$.

The parameter $\alpha$ can be interpreted as one of technological advancement, lowering the cost of adoption over time.

We have parametrized the profits after innovation using an additional parameter $x$, indicating the increase in profits through the new technology, denoting long-run advantage of the new technology. Note that this advantage is lasting even after the follower has also adopted. For the different parameter values that we have tried, refer to Table $3 .{ }^{8}$ In case 3 , we find the possibilities for preemption and precommitment. In the other case, there is no case of preemption because the short-run gain is too low. In the simulation that we will discuss extensively in this section, case 3 , we set the interest rate to be $r=0.04$ and the cost decrease 
Table 3. Simulation parameters and results.

\begin{tabular}{|c|c|c|c|c|c|c|c|c|}
\hline Case & $\pi_{0}(1)$ & $\pi_{0}(0)$ & $\pi_{1}(2)$ & $\pi_{1}(1)$ & $\alpha$ & $r$ & $z \cdot c$ & Result \\
\hline 1 & 1.9 & 2 & $2+x$ & $2.2+x$ & 0.2 & 0.04 & $100 c$ & Precommit \\
\hline 2 & 1.9 & 2 & $2+x$ & $2.2+x$ & 0.1 & 0.04 & $200 c$ & Precommit \\
\hline 3 & 1.9 & 2 & $2+x$ & $3.1+x$ & 0.1 & 0.04 & $100 c$ & Preempt or precommit \\
\hline 4 & 1.9 & 2 & $2+x$ & $2.2+x$ & 0.1 & 0.04 & $100 c$ & Precommit \\
\hline
\end{tabular}

of adopting the new technology over time to be $\alpha=0.1$. We assume that the returns gross of adoption costs are $\pi_{0}(1)=1.9, \pi_{0}(0)=2, \leq \pi_{1}(2)=2+x<\pi_{1}(1)=3.1+x$. In words, being a follower decreases the profits by $5 \%$, whereas the (temporary) leader gains more than $50 \%$ in the short run plus some value $x=\pi_{1}(2)-\pi_{0}(0)$ gross of cost of adoption in the long run. This value of $x$ remains after the follower has caught up and also implemented the new technology. Setting $x$ to zero thus would indicate that - at least in terms of profits no advantage of adoption would remain.

The timing of technology adoption can be calculated both for given (precommitted) leadership and followership according to Equations (18), (19), (22), and (23). Figure 2 plots the timing of adoption for various levels of $x$ or $y \equiv x+\tau$ for foreign and home, respectively. The inner line plots the timing given a firm's precommitment to leading, and the outer line gives the optimal time of adoption given precommitment to follow.

As this figure is based on precommitment, we have to show that firms actually want to be leader or follower. If, for example, both firms would want to lead, a game of preemption will occur in which earlier points of times are chosen than those given in Figure 2. We will deal with preemption further below.

In Figure 3, we plot $L-F$ values for both home and foreign (cf. Equations (24) and (34)) for various levels of $x$ and $y \equiv x+\tau . L-F$ is the profit from leading minus profits from following, and hence as long as it is positive, a firm will attempt to be the first to adopt. The figure graphically illustrates this situation for the home and foreign firm. The area in which the $L-F$ area is above zero, home would like to lead. Areas that are overlapping between those two figures indicate regions of pre-emption. Note that $x$ has the interpretation as above, i.e. continued gain in profits through technology, while $y$ is defined as the sum of $x+\tau$. For the chosen parameter specification and cost functions, the $45^{\circ}$ line of $x=y$, i.e. no environmental tax, is an overlapping region in which both home and foreign would like

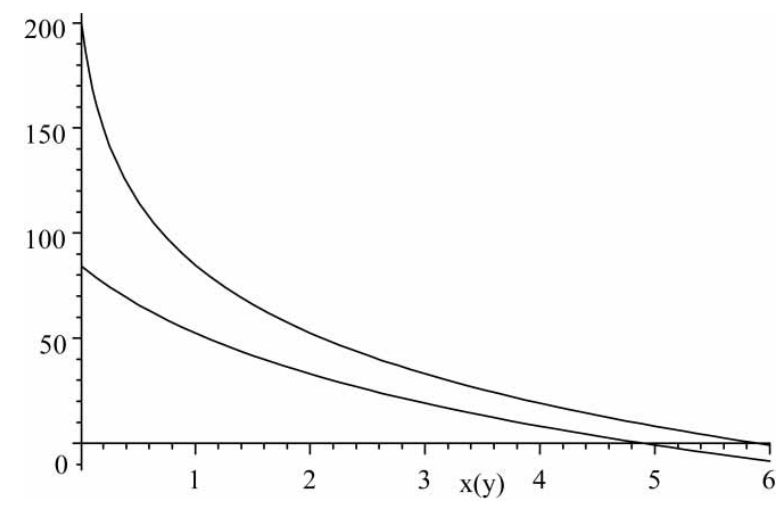

Figure 2. Timing of technology adoption under pre-commitment. 

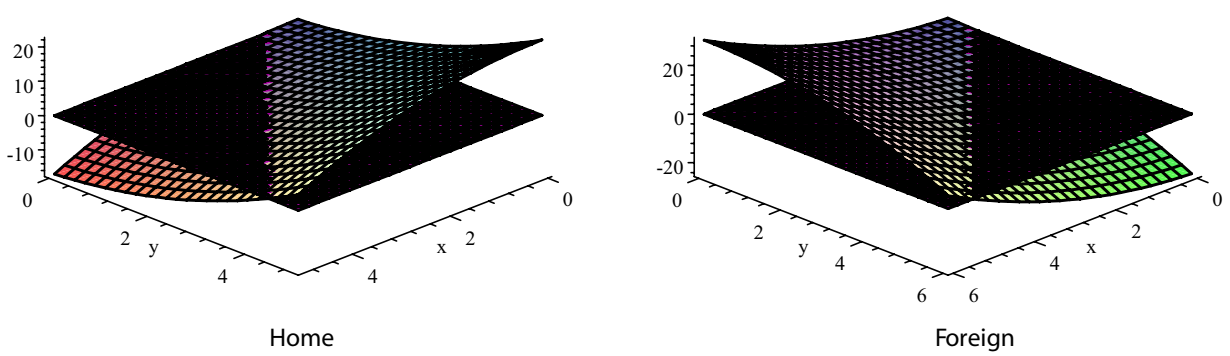

Figure 3. Willingness to lead: $L-F$.

to lead. Hence, preemption would take place by each firm with a $50 \%$ chance (Fudenberg and Tirole 1987). However, for large $\tau>0$, i.e. $x<y=x+\tau$, we can see that both firms are pulled out of the preemption area and home will be the leader $(L-F$ is positive for the home firm), whereas foreign prefers to follow ( $L-F$ is negative for the foreign firm). Only for small values of $x$ and $\tau$ will preemption take place.

PROPOSITION 2.8 If the short-term gain is large enough to allow for a preemption case, low environmental taxes induce a preemption game, which is certainly won by the home firm. The foreign firm will not want to play it. The order of adoption being established, there will be a precommitment outcome of the game. High non-adoption taxes induce a precommitment for the home firm to be the leader directly.

In Figure 4, the 'height' gives the first profitable time $T$ of preemption. Note that the points of time are decreasing for home with the $y$-axis, whereas they are decreasing for foreign along the $x$-axis. Preemption should result with low $\tau$ and precommitment with high environmental taxes $\tau$. In the case of a preemption game, the lower $x$ is (along the $45^{\circ}$ line) and the higher $\tau$ us (moving parallel to the $y$-axis), within the preemption range, the later will be the first profitable point of preemption for the foreign firm. For home, higher environmental taxes lead to earlier profitable points of preemption. Hence, home will have an earlier profitable preemption point of time for any $\tau>0$, therefore, it will preempt just before foreign's first profitable point of preemption (which yields higher profits than home's first profitable point and is sufficient to be the first one to preempt). We can then calculate the profits of preemption as a function of $x$ and $\tau$. Increasing $\tau$ leads to lower preemption profits. Figure 5 summarizes the profits of home as a function of $x$ and $y=x+\tau$. The left figure gives the profits under preemption as a function of $x$ and $y=x+\tau$. Profits are increasing along the $45^{\circ}$ line, and an increase in $\tau$ will lower the profits of the firm. This implies that an environmental taxation does not lead to higher profits of the firms in games of preemption. The right part of Figure 5 gives the profits under precommitment: for small values of $x$ (and $\tau$ ), an increase in environmental taxation will lead to lower profits. Under high levels, this is reversed. Only in this last case, the Porter hypothesis would be supported. However, these high values of $y$ imply negative adoption times and therefore have to be excluded, which one can show by cutting off the graph at the value of $y$ at which there is immediate adoption.

PROPOSITION 2.9 Profits under preemption are lower, the larger the non-adoption tax, and profits under precommitment are lower for higher taxes.

For all other numerical values which do not violate the assumptions of the model, we found results that are qualitatively identical. 

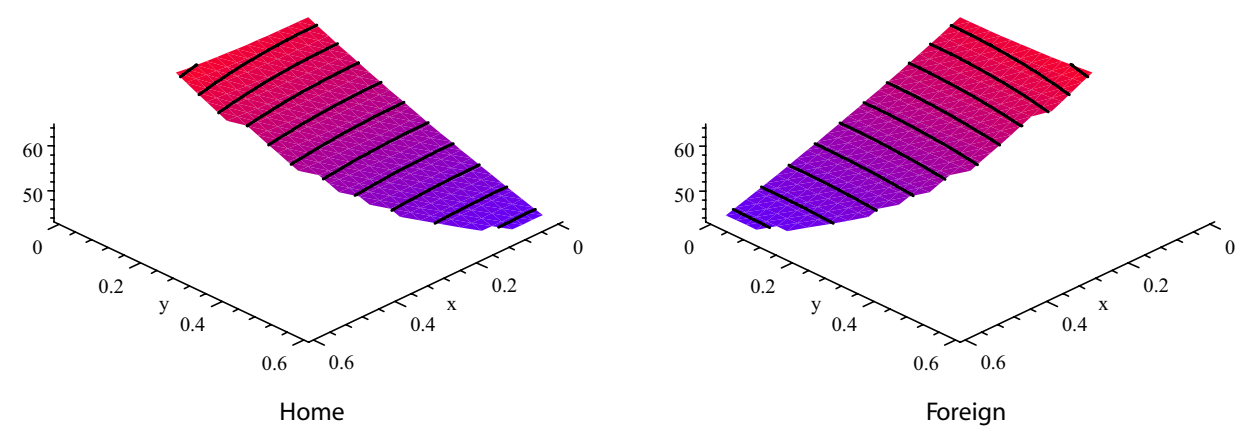

Figure 4. Preemption point of time.
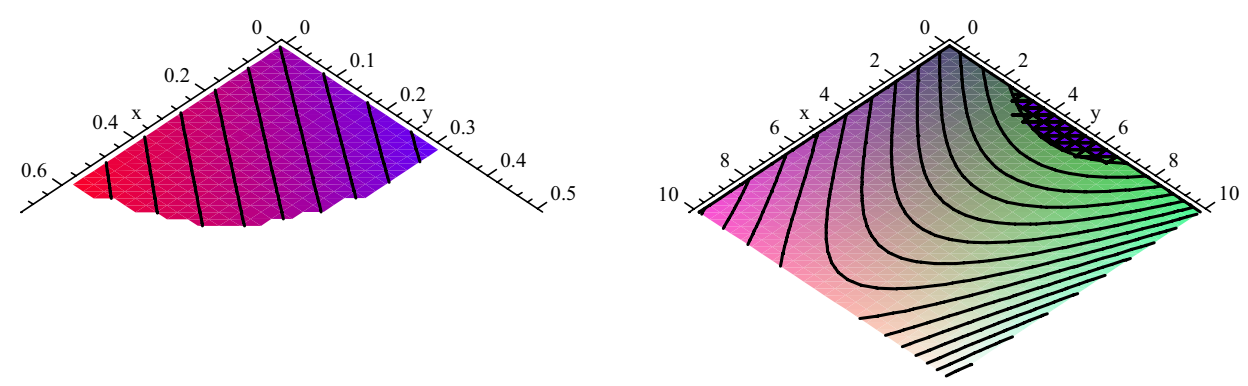

Preemption

Precommitment

Figure 5. Home's profits for preemption and precommitment.

We have shown in this last section that environmental regulation can be beneficial in the strategic games of timing to allow the home firm to lead and avoid preemption. One should bear in mind that this numerical example was contrived and is specific to the parameter values at hand. Many other scenarios can be thought of, which might be just as compelling. Nevertheless, we have shown that an environmental tax allows for a quicker adoption, and a longer time of 'leadership' under precommitment and a shorter time of followership in general. Profits of the firm, however, are not higher. Higher taxes decrease the profits in the first phase of Equation (13) and induce a longer second phase ( $T_{2}^{f}$ is unaffected by $\left.\tau\right)$ and a shorter first phase and higher adoption costs. The net effect is negative.

COROLLARY 2.1 In case of precommitment under no environmental tax, the introduction of a tax decreases profits (anti-Porter). In case of a preemption game under no environmental tax, the introduction of a small tax allows the home firm to win the preemption game, and thus establishes an order of adoption. This leads to a precommitment case which assures higher profits of the home firm compared with the preemption game (pro-Porter).

In essence, we have constructed an example of the weak version of the Porter hypothesis, as firms - maximizing their profits - are pulled out of an equal chance preemption equilibrium in such a way that the firm constrained by the environmental regulation adopts earlier with certainty. Competitiveness in the sense of winning a preemption game is enhanced. Non-environmental as well as environmental welfare is enhanced for consumers of home, as they get higher quality and cleaner products earlier. 


\section{Optimal timing}

In order to obtain a welfare function, we can enhance the profit functions (8), (9), (12), and (13) by adding an environmental damage function, $-D$, consumer benefits, $S$, and tax revenues. Tax revenues and payments then drop out. In the simplest case of a process innovation with no change in consumer benefits, we then only have to add the environmental damage function. Assuming, again for simplicity, that pollution is only national, then a simple assumption for a damage function is

$$
D_{i}^{j}=\int_{0}^{T_{i}^{j}} d_{0} \mathrm{e}^{-r t} \mathrm{~d} t+\int_{T_{i}^{j}}^{\infty} d_{1} \mathrm{e}^{-r t} \mathrm{~d} t \quad \text { with } i=1,2, j=h, f,
$$

depending on whether the country is the home or the foreign country and is adopting first or second. $d_{0}$ is the environmental damage per period before adoption and $d_{1}$ after the adoption. When taking the time derivatives, this will augment the functions (10), (11), (14), and (15) (without tax term) by the term

$$
-\left(d_{0} \mathrm{e}^{-r T_{i}^{j}}-d_{1} \mathrm{e}^{-r T_{i}^{j}}\right)
$$

This term appears where taxes appeared before and have dropped out when canceled against the revenue term. By implication, the old and the new equations are the same in the special case where

$$
\tau=d_{0}-d_{1}>0
$$

In this case, the tax would be a Pigouvian policy instrument, not taking into account strategic interactions between firms and governments. The effect of taking into account damages then is the same as that of taxes as analyzed above: all adoption times are earlier than without taking into account taxes or damages, respectively. In the Cournot literature cited above, the tax was reduced in the second stage game between governments because of the strategic interactions. We do not carry out such a second stage game because it is tractable only in a numerical way anyway and probably not something that governments can reasonably be expected to do for every adoption problem. We did show above that a small tax by one government only may be enough to move the preemption position from a 50/50 chance to one of zero to the home firm. However, if the tax is increased further, profits fall. On the other hand, a higher tax generates an earlier first profitable time of adoption and therefore a strategic advantage in a second stage game. This might give an incentive for governments to put their value above the Pigouvian one. If both governments decide to have the same tax in a symmetric game, there is no impact on the first profitable time of adoption. Home must have a slightly larger tax than foreign, other things equal. The foreign tax can be normalized to unity. Therefore, we concentrated on Porter's case of a one-sided tax. Our analysis as presented above, however, is not limited to a Pigouvian tax, but rather can have any value.

Extending the welfare function for consumer benefits in case of delivery to third markets only is slightly more complicated. It would imply, in one of the possible models we could imagine, considering international welfare and therefore the sum of the profit functions for home and foreign. Consumer benefits then are increased twice, first, when the first firm adopts and offers a better quality probably at a higher price and, second, when the second firm adopts and price competition decreases the price of the better variant. The formal 
treatment then requires adding consumer benefits

$$
S_{i}^{j}=\int_{0}^{T_{1}^{j}} s_{0} \mathrm{e}^{-r t} \mathrm{~d} t+\int_{T_{1}^{j}}^{T_{2}^{j}} s_{1} \mathrm{e}^{-r t} \mathrm{~d} t+\int_{T_{2}^{j}}^{\infty} s_{2} \mathrm{e}^{-r t} \mathrm{~d} t \text { with } j=h, f
$$

to the sum of Equations (8) and (10) or that of Equations (12) and (13) using the adequate $j, h$, or $f$, after adding the environmental damage function and dropping the tax terms as above. We leave the exploration of details to the interested reader, noting that it is an international optimum now, obtained as an enhanced joint profit-maximization problem. It can serve only as a benchmark but not as a recommendation for any international institution, because there is no one deciding on technology adoption or caring for consumer benefits in the sense of this model. A second model we could imagine would be one where welfare is defined as national profits plus benefits of customers abroad. Then a consumer benefit function could be written down, which is completely symmetric to the damage function above. The tax term $\tau$ would then be replaced by $d_{0}-d_{1}-\left(s_{0}-s_{1}\right)>d_{0}-d_{1}$ in the conditions for optimal timing and the marginal consumer benefit would do the same as a tax or the marginal damage, that is inducing earlier adoption times. ${ }^{9}$

\section{Tests of the Porter hypothesis: a theory guided interpretation}

\subsection{Empirical methods and reformulations of the hypothesis}

The essence of the Porter hypothesis is that static calculations of the cost of environmental regulation ignore innovation. If the latter is taken into account, costs are lower and in some cases profits are even enhanced. Based on this, one would expect that analyses, which take into account innovation and have a long-run perspective, should give more lower cost estimates than the static ones or those that ignore technical change. However, what the adequate formulation of the hypothesis is, depends also on the methods which empirical studies use. PL use case studies while others use regression analysis, often in combination with distance functions approaches.

As PL base their arguments on case studies, it is worth emphasizing that they only claim that 'In some cases, these "innovation offsets" can exceed the cost of compliance.' (PL 1995a, 101). This is a fairly weak claim. Stronger formulations, which are cited by some authors, go always accompanied by multiple qualifications of PL, which are sometimes underreported by the authors. What was later called a 'weak version' of the hypothesis differs in its definition from paper to paper. This is also due to differences in emphasis on competitiveness, profits, factor productivity, and productive efficiency either in all markets or in just environmental goods. This requires to go beyond the question whether the Porter hypothesis is right or wrong. Rather we should answer under which conditions and circumstances it is right or wrong. With case study methods - which may be quite a bit more than just anecdotal evidence - it is straightforward to expect differentiations as to the question, under which conditions the hypothesis holds. In regression analysis, one typically looks at the sign and significance of a coefficient. Here we can get more detailed information when comparing for which samples the Porter hypothesis holds and where it does not. In particular, the question from the perspective of economic theory as discussed above is for each data set, whether or not it consists of firms or other units for which one can expect perfect efficiency as in the neoclassical first-principles view, or alternatively, to have situations with agency costs, X-inefficiencies, and managerial slackness, which is emphasized by PL and others, and finally, whether the situation can be described like strategic problems emphasized by the industrial organization literature. Only in the latter two cases we can have innovation 
offsets either for environmental goods or for all goods and firm performance criteria such as (current) profits, productivity changes, productive efficiency, or competitiveness. We will look at this question for all investigations, which have been made with explicit reference to the Porter hypothesis either in the title or in the abstract. ${ }^{10}$

\subsection{Case studies}

There are many case studies that deal with the effect of environmental regulation or taxation on the adaption of new production process, both with and without explicit reference to the Porter hypothesis. We concentrate on the latter cases, without pretending that this overview is exhaustive, rather it should serve as a means to compare them with the theoretical results of the previous section. ${ }^{11}$

Ayres (1994) describes some cases in the utilities and the chemical industry. In particular, Ayres' case study of 'Dow Chemicals' shows that for decennia, the firm has made investment plans irrespective of environmental considerations and then has sent an environmental task force to check for environmental gains, which could produce gains from this second stage for decennia. This is clearly a case of adoption of environmental technologies of the retrofitting type. Adoption can result in an advantage, but only as long as competitors do not do the same thing. Putting then more pressure through environmental policy to do this earlier induces a competitive advantage if done in one country only.

In the Green light program of the US Environmental Protection Agency (USEPA), now called Energy Star, participating firms obtained an advice on efficient lighting, heating and cooling operations for free from the USEPA. Besides the awareness effect, this free advice is an implicit subsidy. The measures taken according to such advice had payback times below two years. Obviously, a firm has an advantage vis-à-vis a competitor only as long as the competitors have not participated as well and obtained a similar free advice (PL 1995a, 99). As far as foreign competitors are concerned, Sweden and the UK followed the USA and so did the EU in 2000. ${ }^{12}$ In the meanwhile, Americans saved $\$ 12$ billions in 2005, of which 1.2 billions was saved by industry (EPA 2005, Table 1$)^{13}$ providing a competitive advantage.

The Dutch Ministry of Economic Affairs provided EUR 425 million for subsidies for investments of firms supporting a $\mathrm{CO}_{2}$-reduction plan during 1997-2002. A similar program was carried out by the Dutch Ministry of Traffic and Infrastructure in 2002-05 for investments in the transport of goods and persons, supporting a volume of $€ 40$ million additional investments, compared to a business as usual scenario, with a subsidy of $€ 9.1$ million buying 160,000 ton $\mathrm{CO}_{2}$ reduction per year to be realized by 2010 for $€ 10$ per ton. For 2006-07, a similar program will be carried out with $€ 6$ million in subsidies. Again it is obvious that a competitive advantage can be obtained by a firm only as long as domestic competitors do not use the program and foreign competitors cannot use a similar program of their own government. ${ }^{14}$

When the Montreal Protocol and the US Clean Air act forbade the use of CFCs, the firm Raytheon adopted a semi-aqueous terpene-based cleaning agent that was of better quality and was produced under lower operating costs. Without mandating the drop of CFCs, this would not have been achieved (PL 1995a, 101). As there was an almost costless alternative, no tax or subsidy was necessary. However, there was a tax on ozone-depleting materials, with an exception for HCFCs replacing the CFCs. This was to the advantage of DuPont, the major producer of HCFCs and its clients (Albrecht 1998a, 1998b).

When a US city threatened to close a jewellery firm (Robbins) because of toxic water pollution, the new system adopted reduced pollution of the water and at the same time 
increased the product quality of the plating, hence competitiveness was improved (PL 1995a, 102). The threat is similar to a non-adoption tax but of course more drastic.

Ciba-Geigy reconsidered its wastewater streams because of new standards. Through a reduction of iron components in a diet, they increased yields by $40 \%$ while reducing toxic releases into the wastewater. This resulted in cost savings of US\$ 740,000 (PL 1995a, 102). Again, standards are similar to non-adoption taxes in that they impose costs, but are of course different in other aspects. ${ }^{15}$

In the second case of Table 4, there is an explicit subsidy. At first, there is a freely available service. Subsidies contain two elements: a pressure and a gain. In the other cases, there are standards, laws, or threats, which combine the elements of pressure and an innovation offset, either in the product or in the process of production. PL provide more cases of pressure from standards and laws with innovation offsets. Not in all cases do we get the full information to check for profitability. However, it is mostly evident that consumers will benefit and firms will react only after some pressure, and in 'some cases' (PL 1995a, 101) the firm gets more profits. What is essential for our model is the similarity of pressure from laws and standards with innovation offsets with the subsidy for adoption or a tax for non-adoption. Moreover, all examples relate to non-immediate adoption, its timing and first mover advantage (and not to R\&D, patenting, scrapping, or capital composition, ${ }^{16}$ which do not appear in the PL articles but are of course also fascinating subjects on their own), and to multinationals in severe international competition.

Roediger-Schluga (2003) has conducted several rounds of interviews in 1999 with heads of R\&D divisions of 28 firms of Austrian manufacturers of printing inks, paints, coatings, and adhesives (SITC 5332, 5334, 59227, 59229) who were confronted with product and process standards for volatile organic compounds (VOCs) in 1996. ${ }^{17}$ These firms spend on average $50 \%$ of their R\&D budgets for compliance with these standards. Single establishment firms spent a higher share on compliance R\&D. There is no deterioration of competitiveness: small firms report to have been negatively affected, but large firms report to have benefited. This clearly points to innovation offsets. Firms report to have adapted their product range, and 15 out of 26 had obtained fresh ideas for new products. Displacements of other R\&D decline with firm size. Compared with PL, who cautiously talk of 'some cases', Roediger-Schluga adds additional cases. Beyond that, his contribution lies in the well-defined sample: it is possible to examine exactly how many cases do or do not correspond to the Porter hypothesis. The small firms for which he finds no support of the Porter hypothesis are neither those whom you expect to have much managerial inefficiency as emphasized by PL, the agency cost interpretation, or the X-inefficiency interpretation,

Table 4. Examples.

\begin{tabular}{|c|c|c|}
\hline Example & Institution & Tax or subsidy equivalent \\
\hline Green light program & USEPA & $\begin{array}{l}\text { Free advice available to all competitors } \\
\quad \text { (Energy Stars) }\end{array}$ \\
\hline $\mathrm{CO} 2$ reduction plan & Dutch Ministries & Subsidy via tax deduction \\
\hline CFC, Raytheon & Montreal Protocol & Tax break on HCFCs US Clean Air Act \\
\hline Ciba-Geigy & Standards & $\begin{array}{l}\text { Standards are almost tax equivalent } \\
\text { wastewater }\end{array}$ \\
\hline Robbins & City's threat of closure & $\begin{array}{l}\text { Threat is similar to non-adoption tax, } \\
\text { toxic water pollution }\end{array}$ \\
\hline Hitachi, Waste & Japanese recycling law & Law is similar to tax equivalent \\
\hline $\begin{array}{l}\text { German laws on CHP and } \\
\text { renewable energy }\end{array}$ & & $\begin{array}{l}\text { Subsidy on market price; specified as } \\
\text { fixed money amount }\end{array}$ \\
\hline
\end{tabular}


nor are they expected to be involved in strategic competition as emphasized by the industrial organization literature to which our model belongs.

\subsection{Distance functions cum regression}

It is almost inherent to the distance function approach that the method detects inefficiencies of some degree because by construct the efficiency has an upper bound of unity, $\mathrm{D} \leq 1$, and no disturbances may bring it to a higher value.

Boyd, Tolley, and Pang (2002) use distance functions and Malmquist-Luenberger indices for the $\mathrm{NO}_{x}$ emissions and the productivity of the US container glass industry. They show that almost half of all plants have inefficiencies in regard to productivity and the environment, as suggested by the Porter hypothesis. Nevertheless, tougher regulations would address all plants and therefore would be costly. Inefficiencies of $>10 \%$ are not observed frequently. The overall impression is that some firms within the industries are very efficient, but not all. The paper does not give the impression that strategic issues are relevant here. Therefore, it contains 'some cases', but is not dominated by offsets.

Murty and Kumar (2003) use the distance function approach for 92 water-polluting firms. Regressing the efficiency measure on a measure of regulation intensity and other variables, they find that regulation enhances efficiency. Efficiencies are indeed low ranging, from a maximum efficiency of 0.62 to a minimum of 0.086 . One does not need strategic issues here to guess that almost any reasonable change can only improve the efficiency.

Kumar and Rao (2003) regress inefficiency results according to the distance function approach on regulation measures and other variables for 33 Indian thermal power plants, half of which have efficiency at or below 0.5 . Environmental standards significantly increase inefficiency, contrary to what the Porter hypothesis states. As inefficiency is large, one might have expected the opposite. The Porter hypothesis obviously does not apply here. However, the authors conclude that this is due to insufficiently strict standards, implying insufficient pressure.

Managi (2004) investigates the impact of environmental regulation on Luenberger productivity indices of US agricultural output and distinguishes between all output, and environmental output. He finds evidence in regard to the environmental output, but not for all output. This is not surprising, as agriculture is neither characterized by problems of attracting managerial time, attention, and information - as emphasized by PL - nor is it in the context of the typical international strategic competition of the PL examples or our model. Managi et al. (2005) find the same result applying the same method to 406 fields in the oil and gas industry in the Gulf of Mexico, which is responsible for $24 \%$ of US production. Obviously, 406 fields are unlikely to play the games typically formulated in the industrial organization literature and our model. Moreover, gas and oil plants are well known to be so highly mechanized that they are unlikely to give rise to the $\mathrm{X}$-efficiency or agency problems, which are typical of long hierarchies and comprehensive bureaucracies of large firms, and therefore other reasons for the inefficiencies found by the distance function need to be found. Unfortunately, the authors do not give us the results of the efficiency measures but rather report fairly conventional TFP growth results. Again, in a simple yes/no type of question, this might seem to be an anti-Porter result, but with some eye on the more sophisticated arguments of PL, one easily sees that these are not the cases where one should expect unused innovation offsets through managerial slackness or strategic advantages.

Marklund (2003) applies the distance function approach to 12 plants of the Swedish pulp industry. The technical efficiency scores are regressed on an environmental regulation 
index. The result is a negative but insignificant effect. This means that there are neither cost increases as predicted by conventional theory nor innovation offsets to an extent leading to positive profits, but still they reach zero. The existence of 12 plants may guarantee enough competition to be sure that the imperfect competition models are irrelevant for them, provided decisions are made at the plant level. The causes of the technical inefficiencies, estimated using distance functions, are not analyzed in the paper.

In regard to the debate about the X-inefficiency of firms, it is remarkable that all studies find some inefficiencies, ${ }^{18}$ but only in the two Indian cases are they large and in one of these do we get strong offsets. 'Some cases' as formulated by PL can be found in the papers by Boyd, Murty and Kumar, and Marklund. US agriculture and gas and oil (Managi 2004) as well as Indian thermal power (Kumar and Rao) are not examples of sectors where one can find any support for PL.

\subsection{Other regression analyses}

Jaffe and Palmer (1997) state explicitly that they do not want to test the Porter hypothesis. They find that the lagged compliance cost variable has a significantly positive impact on $\mathrm{R} \& \mathrm{D}$ expenditures, but an insignificantly negative impact on patenting. They interpret the overall result as inconclusive in regard to the Porter hypothesis. We would like to add though that R\&D expenditures are costs and not offsets, although they bear the potential for offsets in the future. But this is not exactly captured by the approach applied here. For low pay-back times, this should be possible, but not for diffusion processes that take decennia.

Albrecht (1998a,1998b) regresses the change of bilateral exports of refrigerators for households (SITC 7752), industry (7414), and air conditioning (7415) from 1989 (one year after the detection of the ozone problem) to 1995 (one year before the phasing out of CFCs) on several variables, including a dummy for the early adoption of policies against the use of CFCs. For both refrigerator groups, these dummies have clearly positive effects and provide strong evidence for the Porter hypothesis.

Berman and Bui (2001) find that petroleum refineries at the US South coast were having productivity gains of about $5 \%$ compared with other areas with less environmental regulation in a panel analysis with fixed effects. They attribute the corresponding non-adoption of these other areas to uncertainty about cost and efficacy of new technologies and future environmental regulation, which corresponds to 'managerial information' in the words of PL.

Lanoie, Patry, and Lageunesse (2001) make an explicit distinction - in a regression of total factor productivity of 17 manufacturing industry sectors for the years 1985-94between short- and long-run effects by using four lags of the regressor 'investment in pollution abatement equipment'. They find that the Porter hypothesis holds for the less polluting industries and for those which are more exposed to foreign competition. The effects are negative for the contemporaneous investments and for those lagged by one-year, but positive for the second through fourth lag, with later, positive effects dominating the earlier negative ones. For the more polluting industries and those less exposed to foreign competition, there are only insignificant results. Other papers do not have so much emphasis on the distinction between short- and long-run effects.

Alpay, Buccola, and Kerkvliet (2002) provide full information maximum likelihood estimates of a translog version of a restricted short-run profit function for the food manufacturing sector of Mexico and the USA. Using these estimates, they can show that in Mexico, profits are decreased through environmental regulation but productivity is enhanced. The authors speak of a 'strongly confirmed Porter hypothesis'. For the USA, however, they find that effects on both profits and productivity are negligibly small. 
Table 5. Effects of environmental regulation on firm, plant, or sector performance.

\begin{tabular}{|c|c|c|c|}
\hline Level & Authors & Effect on & Sign \\
\hline Dow Chemicals & Ayres (1994) & Profits & + \\
\hline Austrian VOC standard & Roediger-Schluga (2003) & Product innovation (oth.) & + \\
\hline US container glass & $\begin{array}{l}\text { Boyd, Tolley, and } \\
\text { Pang (2002) }\end{array}$ & Productivity, environment & \pm \\
\hline US agriculture & Managi (2004) & Productivity output & - \\
\hline US agriculture & Managi (2004) & $\begin{array}{l}\text { Productivity environment } \\
\text { output }\end{array}$ & + \\
\hline US oil and gas & Managi et al. (2005) & Productivity output & - \\
\hline US oil and gas & Managi et al. (2005) & $\begin{array}{l}\text { Productivity environment } \\
\text { output }\end{array}$ & + \\
\hline Indian water pollution & Murty and Kumar (2003) & Production efficiency & + \\
\hline Indian thermal power & Kumar and Rao (2003) & Production efficiency & - \\
\hline Swedish pulp & Marklund (2003) & Production efficiency & + \\
\hline US manufacturing & Jaffe and Palmer (1997) & $\mathrm{R} \& \mathrm{D}$ & + \\
\hline US manufacturing & Jaffe and Palmer (1997) & Patents & \pm \\
\hline Fridge CFC use & Albrecht (1998a, 1998b) & Export change & + \\
\hline US Petrol refinery & Berman and Bui (2001) & Productivity & + \\
\hline Quebec manufacturing & $\begin{array}{l}\text { Lanoie, Patry, and } \\
\text { Lajeunesse (2001) }\end{array}$ & Productivity & + \\
\hline Mexican food & $\begin{array}{l}\text { Alpay, Buccola, and } \\
\text { Kerkvliet (2002) }\end{array}$ & Productivity (profits) & $+(-)$ \\
\hline US food & $\begin{array}{l}\text { Alpay, Buccola, and } \\
\text { Kerkvliet (2002) }\end{array}$ & Productivity (profits) & $\pm( \pm)$ \\
\hline Dutch agro & $\begin{array}{l}\text { Wossink and Weferink } \\
\text { (2003) }\end{array}$ & Family income & - \\
\hline $\mathrm{NO}_{x}$ Swedish Industry & Isaksson (2005) & Cost of abatement & + \\
\hline $\mathrm{SO}_{2}$ abatement & $\begin{array}{l}\text { de Vries and Withagen } \\
(2005)\end{array}$ & $\begin{array}{l}\text { Patenting abatem. } \\
\text { technology }\end{array}$ & + \\
\hline
\end{tabular}

Note: + denotes an increase, - a decrease of the effect, whereas \pm denotes an unclear or insignificant result.

Wossink and Weferink (2003) regress income of Dutch farmers on the phosphate regulation standards and find that less tough standards lead to higher income. Of course, in Dutch agriculture, one would neither expect imperfect competition nor X-inefficiency, given Holland's legendary thriftiness.

Isaksson (2005) finds positive but low costs for $\mathrm{NO}_{X}$ abatement of 114 plants of three Swedish industries. As the Swedish Environmental protection Agency is told to have had low monitoring cost, the same is likely to hold for the management. Moreover, plants are reported to be small and competitive. By implication, there seem to be neither large management imperfections nor strategic, imperfect competition issues. These plants seem to come close to the no-imperfection benchmark of the first-principles textbook and the anti-Porter views.

In de Vries and Withagen (2005), panel data estimates for 14 countries show that sulphur emissions have a positive impact on patenting of abatement technologies.

In the latter group of studies, those dealing more explicitly with dynamics provide more support for the Porter hypothesis than the other approaches. Three studies on Dutch and US agriculture and Swedish industries have clear anti-Porter results. Five others provide support and one is neutral.

Summarizing, Ayres (1994) and Roediger-Schluga (2003) use firm-level case studies as PL do and find indeed 'some cases' as claimed by PL that have increased in competitiveness as perceived by firms. As PL had made a claim only on 'some cases', it should be clear that indeed they themselves found some cases for enhanced profitability, 
and Roediger-Schluga (2003) found some cases of enhanced perceived competitiveness. Berman and Bui (2001) and Alpay, Buccola, and Kerkvliet (2002) found cases of enhanced productivity. Albrecht (1998a, 1998b) found cases of changes in exports, Lanoie, Patry, and Lajeunesse (2001) found cases of changes in productivity, Jaffe and Palmer (1997) found positive impacts on R\&D, and de Vries and Withagen (2005) found positive impacts on patenting. Some sectors, which seemingly have either no inefficiencies or no strategic power give no support for the Porter hypothesis: Dutch agriculture (Wossink and Weferink), US agriculture and gas and oil (Managi), Indian thermal power (Kumar and Rao), and Swedish industry.

Anti-Porter results are either related (i) to small firms in terms of low numbers of employees and the absence of both management problems and international strategic competition emphasized by the industrial organization literature, or (ii) to short-run methods (Alpay, Buccola, and Kerkvliet 2002), or (iii) to command-and-control methods in environmental policies (Kumar and Rao). Pro-Porter results are obtained in cases where there is no presumption against $\mathrm{X}$-inefficiency, agency costs, and managerial slackness or information problems. Typically in large firms with large bureaucracies, it has a crucial impact of environmental policy on strategic behaviour, which again is only the case when market power is present and therefore is empirically more likely to be observed for large firms.

In short, we find that the evidence, in our interpretation, is not contradicting the theory. When the investigated sample consists of many plants or firms in narrowly defined sectors, imperfect competition is absent and so are strategic issues. If samples consist of small firms, X-inefficiency is unlikely to occur. In these two cases, one cannot expect the Porter hypothesis to hold. In other samples this is different. Cases supporting the Porter hypothesis can be found in samples where the properties of (large) firms with strategic behaviour or $\mathrm{X}$-inefficiency, agency costs, and managerial slackness or information problems cannot be rejected a priori. But it also raises a new question: if the managerial time, alertness, and information are redirected by environmental regulation, where are they distracted from and at what costs? The methods used in the literature discussed above seems not to be particularly designed for these type of questions, and others may be required. An alternative explanation is that emphasis on environmental regulation leads firms to search for new combinations of inputs which are only found because of the regulatory pressure. These ideas point more to imperfect technical information and local learning in the neighbourhood of environmentally relevant aspects of technologies.

In regard to our theoretical result, that a tax turns a preemption game into a precommitment game and provides an international advantage, PL (1995a, 104-5) have three supporting case studies from Germany, Scandinavia, and the USA. Roediger-Schluga (2003) has a data set from Austria, as discussed above, in which the large firms are exposed to and gain in foreign competition in their own perception. Albrecht (1998a, 1998b) found that firms in countries with early policy adoption have higher export changes for household and industry refrigerators. Lanoie, Patry, and Lajeunesse (2001) find that exposition to more foreign rather than domestic competition is more favourable for the Porter hypothesis. This provides some support but also leaves room for more empirical research emphasizing international competition and intertemporal aspects explicitly. Testing our own results will be difficult because the argument of Smith and Walsh (2000) that the counterfactual will always be missing applies all the more to the preemption game where a firm wins (looses) with a $50 \%$ chance ex-ante, but ex-post the probabilities are zero after having lost and unity after having won. The ex-ante probabilities will never be known and neither will the transition to the ex-post probabilities. Also we are not aware of empirical methods for testing for the presence of a preemption game. 
Given the many combinations obtained from the properties of small/large firms, efficient/inefficient, good/bad regulation modes, short-run versus dynamic analysis, the number of cases analysed is still low so far, but theory and evidence of the literature triggered by PL can be reconciled once one does not over-interpret the Porter hypothesis. For practical policy though, this means that one needs a good knowledge of the properties of the sectors, a good anticipation of its reaction, and a clear idea how much of a cost increase one is willing to impose for environmental purposes.

\section{Conclusion}

Given the prominent role of innovation offsets in the Porter hypothesis, we did prefer to model it using a framework of technology adoption by Fudenberg and Tirole. In the stationary version of the model, non-adoption is an equilibrium outcome, although firms are profit maximizing.

In our dynamic version of the technology adoption model, early adoption is more costly than late adoption. By implication, immediate adoption cannot be expected and an equilibrium with time periods where a new technology is not adopted by profit-maximizing firms is a rational outcome.

In the national case, under precommitment on the order of adoption, the leader and the follower adopt earlier if the environmental tax is larger. Under preemption, the timing of preemptive adoption will be earlier if the environmental tax is higher. Joint late adoption takes place earlier under a higher environmental tax.

In the international case, the home country raises a tax but the foreign country does not. Under precommitment on the order of adoption, if home is the follower, it adopts earlier if the environmental tax is larger, decreasing the time that a foreign firm can reap the benefits of early adoption. Comparing behaviour as follower, foreign adopts slower than home because in the foreign country there is no environmental tax by assumption. If there is a preemption game, a non-adoption tax in one country ensures that the firm in that country can preempt earlier than the firm in the other country. The home firm preempts just before the foreign firm would do. The chance of preemption jumps from $50 / 50$ to $100 \%$ for the home country if there is an environmental tax. The case of preemption will exist under a low environmental tax only if the temporary gains of the first adoption are high relative to the temporary losses of the second.

If home wins the preemption game with certainty, due to the environmental tax, foreign, foreseeing this, limits itself to following. The resulting game then is one of precommitment.

Under high non-adoption taxes or low temporary gains and losses, there is a precommitment for home to be the leader anyway. Ex-post profits of the home firm are lower under precommitment the larger the tax is. In sum, a tax introduces a reduction in ex-post profits in a precommitment game (anti-Porter), but also turns a preemption game into one of precommitment, which yields higher profit (pro-Porter).

The empirical evidence of both sector and case studies can be reconciled with our findings. The original paper by PL has case studies of international advantage in adoption settings, but also newer literature from Austria and Germany. In general, case studies under more imperfect settings and with a clearer adoption type of production process confirm our theoretical findings. The review of the case studies reveals that in several cases innovation offsets can be observed with subsidies. Other evidence is in support of the hypothesis in sectors with large firms and strategic activity where firms have X-inefficiency and agency costs such as managerial time, alertness, and information. 


\section{Acknowledgements}

We would like to thank the editor and two anonymous referees for their valuable comments.

\section{Notes}

1. $\tau$ could also be introduced by using country-specific cost functions; however, our purposes treating it as a separate 'cost' serves our purpose best.

2. The number in brackets is the number of firms that have adopted: 0,1 , or 2 . The subscript $1(0)$ indicates that a firm has (not) adopted.

3. The cost of adoption, $c(t)$, is defined to be the present value of the cost of adopting the new technology at time $t$.

4. The first $T$ on the left-hand side denotes the firm's own adoption time, the second the other firm's adoption time.

5. Stated differently, given both technologies without any cost of adoption, the new technology would always be preferred.

6. See Propositions 2.6 and 2.8 .

7. A large $\pi_{0}(1)$ makes the desire to lead weaker, because it gives a higher weight to the timing shift effect. But a larger $\pi_{2}(1)$ has opposing effects directly and from Equation (5).

8. The parameter values presented in the table give the most relevant variations for this simulation exercise. We have tried other parameter values, which confirm the results we present here.

9. A complication arises here if a customer switches to the foreign competitor after adoption of the home firm. It is reasonable to assume that this does not decrease the total benefit of the consumers of the home firm.

10. This implies that we do not look again at some papers of the older literature, which have been made independently of but published during the same years as the PL papers and tackled the Porter hypothesis only as a side remark. Exceptions are papers, which are held to be relevant by several other papers selected (from the Journal of Economic Literature and the literature database 'econpapers') in the above-mentioned manner. Ambec and Barla (2005), by virtue of writing earlier, consider less recent literature, more old literature, emphasize the energy sector and econometric methods, and by implication ignore case studies.

11. Table 5 summarizes the results of the papers. See also Ambec and Lanoie (2007) for an overview of related papers.

12. International Association for Energy-Efficient Lighting (IAEEL), IAEEL Newsletter 1 (1999).

13. Energy Star And Other Climate Protection Partnerships, 2005 Annual Report.

14. SenterNovem, Projectenboek $\mathrm{CO}_{2}$-reductieplan, October 2005. Similar forerunner programs have been discussed by Steger et al. (2004, section 7.3.1).

15. Many other examples can be found in PL (1995a, 1995b, in particular on page 123) and in IAEEL (1999).

16. Capital composition is discussed in Xepapadeas and de Zeeuw (1999) and in Feichtinger et al. (2005). Note in particular that additional R\&D and patenting through regulation are additional costs as suggested by the neoclassical static first principles, which still need to be transformed into profits, productivity, etc. Therefore, they should not be interpreted as support for the Porter hypothesis unless they lead to higher profits as in some of the two-stage Cournot models.

17. Interpretation of his calculations of revealed comparative advantage indices gives no clear results because they suffer from the EU accession in 1995 with its trade diversion and creation effects and the recession in 1998 in connection with the Austrian budget deficit reductions. For a discussion of early papers using cost function estimates and the associated problems, see Smith and Walsh (2000).

18. To the extent that these inefficiencies reflect different technologies, the question is why technologies are different. Are there reasons for differences in timing of adoption with the limiting case of never adopting?

\section{References}

Albrecht, J.A. 1998a. Environmental costs and competitiveness. A product-specific test of the Porter hypothesis. SSRN eLibrary. http://papers.ssrn.com/sol3/papers/.cfm?abstract_id=137953 (accessed January 23, 2008). 
Albrecht, J.A. 1998b. Environmental regulation, comparative advantage and the Porter hypothesis. SSRN eLibrary. http://papers.ssrn.com/sol/papers/.cfm?abstract_id=135608 (accessed January 23, 2008).

Alpay, E., S. Buccola, and J. Kerkvliet. 2002. Productivity growth and environmental regulation in Mexican and U.S. food manufacturing. American Journal of Agricultural Economics 84, no. 4: 887-901.

Ambec, S., and P. Barla. 2002. A theoretical foundation of the Porter hypothesis. Economic Letters 75, no. 3: 355-60.

Ambec, S., and P. Barla. 2005. Can environmental regulations be good for business? An assessment of the porter hypothesis. Cahiers de recherche 0505 , Universit Laval-Dpartement d'conomique.

Ambec, S., and P. Lanoie. 2007. When and why does it pay to be green? Technical Report 2007-2005, Working Paper GAEL, Montreal.

Ayres, R.U. 1994. On economic disequilibrium and free lunch. Environmental and Resource Economics 4, no. 5: 435-54.

Barrett, S. 1994. Strategic environmental policy and international trade. Journal of Public Economics 54, no. 3: 325-38.

Berman, E., and L.T.M. Bui. 2001. Environmental regulation and productivity: Evidence from oil refineries. The Review of Economics and Statistics, 83, no. 3: 498-510.

Boyd, G.A., G. Tolley, and J. Pang. 2002. Plant level productivity, efficiency and environmental performance of the container glass industry. Environmental and Resource Economics 23: 29-43.

de Vries, F., and C. Withagen. 2005. Innovation and environmental stringency: The case of sulfur dioxide abatement. Technical Report 2005-2018, Tilburg University, Tilburg.

Feess, E., and G. Taistra. 2000. Porter's hypothesis on environmental policy in an oligopoly model with cost asymmetry caused by innovation. Jahrbücher für Nationalökonomie und Statistik 220, no. $1: 18-31$.

Feichtinger, G., R. Hartl, P. Kort, and V. Veliov. 2005. Environmental policy, the Porter hypothesis and the composition of capital: Effects of learning and technological progress. Journal of the Environmental Economics and Management 50: 434-46.

Fudenberg, D., and J. Tirole. 1985. Preemption and rent equalization in the adoption of new technology. Review of Economic Studies 52, no. 3: 383-401.

Fudenberg, D., and J. Tirole. 1987. Understanding rent dissipation: On the use of game theory in industrial organisation. American Economic Review, 77, no. 2: 176-83.

Greaker, M. 2003. Strategic environmental policy; eco-dumping or a green strategy? Journal of Environmental Economics and Management, 45, no. 3: 692-707.

Hoppe, H. 2002. The timing of new technology adoption: theoretical models and empirical evidence. The Manchester School 70, no. 1: 56-76.

Hübner, M. 2001. Sleeping process patents and environmental innovation. Jahrbücher für Nationalökonomie und Statistik 222, no. 6: 706-18.

International Association for Energy-Efficient Lighting (IAEEL). 1999. IAEEL Newsletter. IAEEL website. http://www.iaeel.org/.

Isaksson, L.H. 2005. Abatement costs in response to the Swedish charge on nitrogen oxide emissions. Journal of Environmental Economics and Management 50: 102-20.

Jaffe, A.B., and K. Palmer. 1997. Environmental regulation and innovation: A panel data study. The Review of Economics and Statistics 79, no. 4: 610-19.

Klein, M., and J. Rothfels. 1999. Can environmental regulation of X-inefficient firms create a 'double dividend'?, Technical Report 103, Institut für Wirtschaftsforschung Halle, Halle.

Kumar, S., and D.N. Rao. 2003. Environmental regulation and production efficiency: A case study of the thermal-power sector in India. The Journal of Energy and Development, 29, no. 1: 81-94.

Lanoie, P., M. Patry, and R. Lajeunesse. 2001. Environmental regulation and productivity: New findings on the Porter analysis. CIRANO WP 2001s-53, Montreal.

Managi, S. 2004. Competitiveness and environmental policies for agriculture: Testing the Porter hypothesis. International Journal of Agricultural Resources, Goveranance and Ecology 3, nos. 3-4: 309-24.

Managi, S., J.J. Opaluch, D. Jin, and T.A. Grigalunas. 2005. Environmental regulations and technological change in the offshore oil and gas industry. Land Economics 81, no. 2: 303-19.

Marklund, P.-O. 2003. Environmental regulation and firm efficiency: Studying the Porter hypothesis using a directional output distance function. Umea Economic Studies 619, Umea University, Department of Economics. 
Mohr, R.D. 2002. Technical change, external economies, and the Porter hypothesis. Journal of Environmental Economics and Management 43, no. 1: 158-68.

Murty, M.N., and S. Kumar. 2003. Win-win opportunities and environmental regulation: Testing of Porter hypothesis for Indian manufacturing industries. Journal of Environmental Management 67, no. 2: 139-44.

Osang, T., and A. Nandy. 2003. Environmental regulation of polluting firms: Porter's hypothesis revisited. Brazilian Journal of Business Economics 3, no. 3: 128-48.

Palmer, K., W.E. Oates, and P.R. Portney. 1995. Tightening environmental standards: The benefit-cost or the no-cost paradigm. Journal of Economic Perspectives 9, no. 4: 119-32.

Popp, D. 2005. Uncertain R\&D and the porter hypothesis. Contributions to Economic Analysis and Policy 4, no. 1: 1-14.

Porter, M.E. 1991. America's green strategy. Scientific American 264, no. 4: 168.

Porter, M.E., and C. van der Linde. 1995a. Toward a concept of the environment competitiveness relationship. Journal of Economic Perspectives 9, no. 4: 97-118.

Porter, M., and C. van der Linde. 1995b. Green and competitive: Ending the stalemate. Harvard Business Review 73, no. 5: 120-34.

Reinganum, J.F. 1981. On the diffusion of new technology: A game theoretic approach. Review of Economic Studies 48, no. 3: 395-405.

Roediger-Schluga, T. 2003. Some micro-evidence on the 'Porter Hypothesis' from Austrian VOC emission standards. Growth and Change 14, no. 3: 359-79.

Schmutzler, A. 2001. Environmental regulations and managerial myopia. Environmental and Resource Economics 18, no. 1: 87-100.

Simpson, D.R., and R.L. Bradford III. 1996. Taxing variable cost: Environmental regulation as industrial policy. Journal of Environmental Economics and Management 30, no. 3: 282-300.

Smith, V.K., and R. Walsh. 2000. Do painless environmental policies exist? Journal of Risk and Uncertainty 21, no. 1: 73-94.

Steger, U., W. Achterberg, K. Blok, H. Bode, W. Frenz, C. Gather, G. Hanekamp, D. Imboden, M. Jahnke, M. Kost, R. Kurz, H.G. Nutzinger, and T.H. Ziesemer. 2004. Sustainable Development and Innovation in the Energy Sector. Springer: Berlin.

Tirole, J. 1988. The theory of industrial organisation. Cambridge, Massachusetts: MIT Press.

Ulph, A. 1996a. Environmental policy and international trade when governments and producers act strategically. Journal of Environmental Economics and Management 30, no. 3: 265-81.

Ulph, A. 1996b. Strategic environmental policy and international trade - the role of market conduct. In Environmental Policy and Market Structure, ed. C. Carraro, Y. Katsoulaeos, and A. Xepapadeas, 99-127. Dordrecht: Kluwer Academic Publishers.

Wossink, A., and F. Weferink. 2003. Hot spots in animal agriculture, emerging federal environmental policies and the potential for efficiency and innovation offsets. Journal of Agricultural Resources, governance and Ecology 2, nos. 3-4: 228-42.

Xepapadeas, A., and A. de Zeeuw. 1999. Environmental policy and competitiveness: The Porter hypothesis and the composition of capital. Journal of Environmental Economics and Management 37: 165-82. 